\title{
Precursor-dependent structural properties and antibacterial activity of copper oxide
}

\author{
DIPTI V DHARMADHIKARI, APARNA S PHIRANGE, SUSHMA G SABHARWAL \\ and ANJALI A ATHAWALE* \\ Department of Chemistry, Savitribai Phule Pune University, Pune 411007, India \\ *Author for correspondence (agbed@ chem.unipune.ac.in)
}

MS received 21 July 2017; accepted 17 November 2017; published online 18 July 2018

\begin{abstract}
Inorganic metal oxide nanoparticles of zinc, copper and iron have been widely studied for their use in biomedical research due to their novel physical, chemical and biological properties. Present work involves studies on copper oxide nanoparticles for their antibacterial activity. Copper oxide $(\mathrm{CuO})$ nanoparticles were synthesized by template-free hydrothermal synthesis using different precursors of copper (nitrate, acetate, chloride and sulphate). The samples were characterized by Fourier transform infrared spectroscopy (FTIR), X-ray diffraction (XRD) analysis, ultraviolet-visible (UV-Vis) absorption spectroscopy, scanning electron microscopy (SEM) and zeta potential analysis. The XRD patterns of the synthesized samples show presence of $(-111)$ and (111) planes, which can be assigned to the monoclinic phase of $\mathrm{CuO}$ with the average crystallite size ranging between 43 and $49 \mathrm{~nm}$. The SEM reveals rod-shaped morphology of the samples with a broad size distribution. The optical band gap calculated by UV-Vis absorption study ranges between 1.35 and $1.38 \mathrm{eV}$. The highly negative zeta potential values of the $\mathrm{CuO}$ synthesized with nitrate $(-23.78 \pm 0.95 \mathrm{mV})$, acetate $(-11.86 \pm 1.06 \mathrm{mV})$ and sulphate $(-22.33$ $\pm 0.85 \mathrm{mV}$ ) precursors of copper reveal the good colloidal stability of the synthesized particles. While CuO synthesized with copper (II) chloride shows intermediate stability with the zeta potential as $9.40 \pm 1.86 \mathrm{mV}$. The antibacterial activity of the synthesized $\mathrm{CuO}$ was studied against human pathogens like Escherichia coli (E. coli) and Staphylococcus aureus (S. aureus) bacterial strains, which are proved to be efficient and precursor-dependent. The minimum inhibitory concentration of $\mathrm{CuO}$ against $E$. coli and $S$. aureus were found to be 0.15 and $0.1 \mathrm{mg} \mathrm{ml}^{-1}$, respectively. $\mathrm{CuO}$ nanoparticles exhibit good antibacterial activity, hence, it has potential for biomedical applications in preventing and treating infections.
\end{abstract}

Keywords. Template-free hydrothermal synthesis; antibacterial activity; structural characterization; optical properties.

\section{Introduction}

Copper oxide $(\mathrm{CuO})$ nanoparticles are known to be stable, robust and have a longer shelf life; hence, they were effectively used for purification of water, textile industry, water disinfection, medicine, food packaging, etc. Recently, it was used as an antibacterial agent against various bacterial species. The bactericidal property of nanoparticles depends on their size, stability and concentration of nanoparticles added to the growth medium [1-3]. It was reported that the use of $\mathrm{CuO}$ reduces the existence of hospital-acquired infections and the cost of health care facilities. One of the most interesting innovations in the medical care (hospital textile) is the bed sheets containing $\mathrm{CuO}$ nanoparticles, which reduce the microbial attachment and thus, it helps in preventing the microbial infections within hospitals [4].

The properties of various metal oxide nanoparticles are reported to be affected by the method of preparation as well as the type of precursors used [4-16]. Various methods were used to synthesize copper oxide. The critical reaction conditions such as temperature, reaction time, pressure, template assistance and structure directing agent are subjects of paramount concern in these methods [2,17-25]. Among various methods of synthesis, hydrothermal method is one of the popularly used method due to its simplicity, low temperature and pressure, template-free and cost-effective synthesis. Azimirad et al [9] have synthesized $\mathrm{CuO}$ by hydrothermal method using various precursors of copper in presence of CTAB as a structure directing agent. Synthesis of copper oxide nanosheets was reported by Zhao et al and Outokesh et al [26,27].

The present work focusses on the template-free hydrothermal synthesis of copper oxide nanoparticles using different copper precursors (nitrate, acetate, chloride and sulphate). Different analytical techniques such as Fourier transform infrared spectroscopy (FTIR), X-ray diffraction (XRD) analysis, ultraviolet-visible (UV-Vis) absorption spectroscopy, scanning electron microscopy (SEM) and zeta potential measurements were used to confirm the product formation and to characterize the materials. The antibacterial performance of the synthesized copper oxide nanoparticles was investigated using Escherichia coli (E. coli; Gram negative) and Staphylococcus aureus (S. aureus; Gram positive) bacteria. The process of cell damage could be observed wih the help of SEM. 
The present work gives first hand report on precursordependent antibacterial activity of template-free hydrothermally synthesized copper oxide nanoparticles against the human pathogens ( $E$. coli and $S$. aureus) and the cytotoxicity of the copper oxide nanorods (for HeLa cell lines) is significant as observed from the results.

\section{Material and methods}

\subsection{Synthesis of copper oxide}

All the chemicals used for experimental purpose were of analytical grade and were used without further purification. Copper (II) nitrate trihydrate $\left(\mathrm{Cu}\left(\mathrm{NO}_{3}\right)_{2} \cdot 3 \mathrm{H}_{2} \mathrm{O}, 99.5 \%\right)$ and Copper (II) chloride dihydrate $\left(\mathrm{CuCl}_{2} \cdot 2 \mathrm{H}_{2} \mathrm{O}, 99.0 \%\right)$ were from Merck. Cupric sulphate $\left(\mathrm{CuSO}_{4} \cdot 5 \mathrm{H}_{2} \mathrm{O}, 99.5 \%\right)$ was from Qualigens and Cupric acetate monohydrate $\left(\left(\mathrm{CH}_{3} \mathrm{COO}\right)_{2}\right.$ $\left.\mathrm{Cu} \cdot \mathrm{H}_{2} \mathrm{O}, 99.0 \%\right)$ was from Loba Chemie, India. Potassium hydroxide $(\mathrm{KOH})$ extra pure pellets were from Sisco Research Laboratory (SRL). Double-distilled water was used wherever necessary.

Hydrothermal method was employed for the synthesis of copper oxide. For this, $1 \mathrm{mmol}$ of cupric nitrate was dissolved in $\sim 10 \mathrm{ml}$ of double-distilled water and mixed properly to obtain a homogeneous solution. The solution was then heated on a hot plate at $80^{\circ} \mathrm{C}$ for few minutes to obtain a dry mass followed by the addition of $5 \mathrm{mmol}$ of $\mathrm{KOH}$ as a hydrolysing agent. To this, appropriate volume of water was added and the mixture was transferred to a Teflon-lined stainless steel autoclave and subjected to hydrothermal activation at $140^{\circ} \mathrm{C}$ under autogenous pressure for $6 \mathrm{~h}$. After $6 \mathrm{~h}$, the autoclave was allowed to cool to room temperature naturally. The product obtained as a black precipitate was centrifuged and washed repeatedly with distilled water to remove water-soluble impurities and then with methanol and dried at room temperature. The powder was heated in a muffle furnace (Kumar, Fourtech Lab Furnace) at $350^{\circ} \mathrm{C}$ for $2 \mathrm{~h}$ to obtain pure phase product.

Similar procedure was adopted for the synthesis of copper oxide using other precursors; copper acetate, chloride and sulphate. The products thus obtained using different precursors of copper are represented as follows:

Sample a: Copper oxide synthesized with cupric nitrate as precursor.

Sample b: Copper oxide synthesized with cupric acetate as precursor.

Sample c: Copper oxide synthesized with cupric chloride as precursor.

Sample d: Copper oxide synthesized with cupric sulphate as precursor.

All the products were characterized by FTIR spectroscopy, XRD analysis, UV-Vis absorption spectroscopy, SEM and zeta potential analysis.

\subsection{Characterization of materials}

FTIR spectra were recorded on a Shimadzu 8400 infrared spectrophotometer using $\mathrm{KBr}$ as a reference material in the frequency range of $400-4000 \mathrm{~cm}^{-1}$. The crystal phase and crystallite size of the products were determined by XRD analysis on a Bruker D8 Advance Diffractometer using Ni-filtered $\mathrm{CuK} \alpha$ radiation $\left(\lambda=1.5406 \AA\right.$ ) in $2 \theta$ range of $20-80^{\circ}$ at room temperature, silicon was used as an external standard for correction due to instrumental broadening. The average crystallite size of the powder was estimated by Scherrer formula. Crystal phases were identified by comparing the analysis data with JCPDS (Joint committee on powder diffraction system) database. The UV-visible absorption spectra of the samples were recorded using UV-3600, UV-visible spectrophotometer in the wavelength ranging from 200 to $2500 \mathrm{~nm}$ using $\mathrm{BaSO}_{4}$ as a standard. The theoretical band gap of the pure phase products was calculated from the absorption spectra. The morphological characteristics of the samples were assessed with the help of SEM (JEOL, JSM-6360A electron microscope). Images of the samples were recorded by coating the samples with a thin film of Ag-Pd alloy by vapour deposition technique. Zeta potential of the samples was measured using Brookhaven's NanoBrook 90 Plus PALS zeta potential analyzer by dispersing the $\mathrm{CuO}$ particles in milli $\mathrm{Q}$ water followed by ultrasonication for 3-5 min.

\subsection{SEM studies for antibacterial activity}

The morphological changes taking place in the E. coli and $S$. aureus bacteria upon treatment with the copper oxide nanomaterials (samples a-d) were studied with the help of SEM. The treated and control bacterial cells were incubated at $37^{\circ} \mathrm{C}$ for $24 \mathrm{~h}$. After $24 \mathrm{~h}$, the bacterial cells were harvested, fixed in glutaraldehyde (3\% v/v, phosphate buffer, $\mathrm{pH} 7)$ and dehydrated by sequential treatment with 50, 60, 70, 80, 90 and $95 \%$ ethanol for $20 \mathrm{~min}$ and then, the cells were kept in absolute ethanol for $1 \mathrm{~h}$. The dried cells were sputter-coated with platinum for SEM imaging.

\subsection{Test for antibacterial activity}

2.4a Bacterial culture: The antibacterial effect of hydrothermally synthesized copper oxide nanoparticles was tested using two common bacterial stains: Gram negative (E. coli) and Gram positive ( $S$. aureus). The E. coli and $S$. aureus were cultivated in Luria-Bertani (LB) nutrient broth at $37^{\circ} \mathrm{C}$ for $24 \mathrm{~h}$ to achieve the exponential growth phase. The cells were collected by centrifugation and washed with saline solution $(0.85 \% \mathrm{NaCl}, \mathrm{pH} 7)$ and then re-suspended in physiological saline solution $(0.85 \% \mathrm{NaCl})$ to maintain the concentration of $10^{7}-10^{8}$ colony-forming units (CFU) per $\mathrm{ml}\left(\mathrm{CFU} \mathrm{m}{ }^{-1}\right)$. The optimal density of bacterial cells was adjusted to 0.5 McFarland standards. All the glass apparatus and solutions used in the experiments were autoclaved at $121^{\circ} \mathrm{C}$ for $20 \mathrm{~min}$ to maintain sterile conditions. 
2.4b Determination of MIC: The E. coli and S. aureus bacterial cultures were used initially to determine the minimum inhibitory concentration (MIC) of the nanomaterials. The MIC is defined as the lowest concentration of material that inhibits the growth of an organism. The MIC for both the bacteria were determined as follows. The copper oxide samples were dispersed in milli $\mathrm{Q}$ water by ultrasonication. Different concentrations of samples $\mathrm{a}-\mathrm{d}(0.05-0.7$ $\mathrm{mg} \mathrm{ml} \mathrm{m}^{-1}$ ) were added in $2 \mathrm{ml} \mathrm{LB}$ broth. The density of E. coli and $S$. aureus cells were adjusted to $10^{7}-10^{8} \mathrm{CFU}$ $\mathrm{ml}^{-1}$ and inoculated into the above suspension followed by incubation at $37^{\circ} \mathrm{C}$. Bacterial growth was observed by measuring the optical density (absorbance) after every $1 \mathrm{~h}$ time interval at $600 \mathrm{~nm}$ wavelength. The lowest concentration of $\mathrm{CuO}$ at which no observable bacterial growth is seen is considered as the MIC value. The experiments were carried out in three replicates. Cultures of medium without the nanoparticles under similar growth conditions were used as a control. The experiments also included a positive control (a flask containing the nanoparticles and nutrient media, devoid of inoculums) and a negative control (flask containing inoculums and nutrient media, devoid of the nanoparticles).

2.4c Cell viability tests and percentage of inhibition: The colony count method was adopted for cell viability tests of $E$. coli and $S$. aureus bacterial cells. Ten microlitres of bacterial cells were added to $2 \mathrm{ml}$ of the test solution containing different concentrations of the nanoparticles in a test tube. Cell viability is an assay to determine the ability of cells to maintain or recover viability. These tubes were incubated at $37^{\circ} \mathrm{C}$ for 4 and $6 \mathrm{~h}$, respectively, for E. coli and S. aureus under shaking conditions. The viability of the bacterial cells was evaluated by the colony count method as follows: after suitable dilution with saline, the above mixture was spread on LB agar plates. The plates were then incubated at $37^{\circ} \mathrm{C}$ for $24 \mathrm{~h}$. Corresponding controls were run simultaneously as above. Bacterial growth inhibition was calculated by counting colonies and compared to those on control plates as shown in equation (1). All treatments were carried out in duplicate and repeated thrice to check the reproducibility.

Bacterial growth inhibition $\%=\frac{C_{\mathrm{c}}-C_{\mathrm{s}}}{C_{\mathrm{s}}} \times 100$.

where $C_{\mathrm{c}}$ and $C_{\mathrm{s}}$ represent colony count of control (untreated) and samples (treated), respectively.

All assays were repeated three times in dupicate to ensure uniform results. Standard deviation $(S)$ was calculated in terms of standard error using equation (2).

$$
S=\sqrt{\frac{1}{N-1} \sum_{i=1}^{N}\left(x_{i}-\bar{x}\right)^{2}}
$$

where $\left(x_{1}, x_{2}, x_{3}, \ldots, x_{i}\right)$ are the observed values of the sample and $\bar{x}$ is the mean value of these observations, $(N-1)$ is known as Bessel's correction [28]. The growth profiles were obtained by measuring the absorbance of the incubated $\left(37^{\circ} \mathrm{C}\right.$ for $24 \mathrm{~h})$ solutions containing fixed concentration $\left(10^{7}-10^{8}\right.$ CFU ml ${ }^{-1}$ ) of cells (E. coli and S. aureus) as control and with $\mathrm{CuO}$ nanoparticles as a function of time at $600 \mathrm{~nm}$ wavelength.

\subsection{Determination of cytotoxicity}

2.5a Cell culture: HeLa cell line was obtained from the National Centre for Cell Science, Pune, India. Approximately $1 \times 10^{5} \mathrm{ml}^{-1}$ cells (HeLa cell lines) in their exponential growth phase were seeded in a flat-bottomed 96 -well polystyrenecoated plate and were incubated for $24 \mathrm{~h}$ at $37^{\circ} \mathrm{C}$ in a $\mathrm{CO}_{2}$ incubator.

2.5b MTT assay: Cell viability was evaluated using 3(4,5-dimethylthiazol-2-yl)-2,5-diphenyltetrazolium bromide (MTT). This assay is based on the metabolic reduction of soluble MTT by the mitochondrial enzyme activity of viable cells into an insoluble coloured formazan product, which can be measured spectrophotometrically after dissolution in Dimethyl sulfoxide. HeLa cancer cell lines were seeded in well-type tissue culture plates and kept in $\mathrm{CO}_{2}$ incubator for $24 \mathrm{~h}$. Stock solutions of the copper oxide nanoparticles (samples a-d) were prepared in sterile distilled water and diluted to the required concentration using a cell culture medium and finally, nanoparticles were passed through sterile $0.2 \mu \mathrm{M}$ filter to avoid contamination. A series of dilutions $(6.25,12.5$, $25,50,100$ and $200 \mu \mathrm{g} \mathrm{ml}^{-1}$ ) of copper oxide nanoparticles were added to the cultures to obtain respective concentrations of nanoparticles, which were further incubated for $24 \mathrm{~h}$ in $\mathrm{CO}_{2}$ incubator. After $24 \mathrm{~h}$ of incubation, $10 \mathrm{ml}$ of MTT reagent was added to each well and further kept for $4 \mathrm{~h}$ incubation. The purple coloured formazan formed after $4 \mathrm{~h}$ in each well were dissolved by the addition of $150 \mu \mathrm{l}$ of detergent for $5 \mathrm{~min}$ and the plates were read immediately on a microplate reader at $570 \mathrm{~nm}$ and the viability was calculated. The amount of formazan product was determined by measuring the absorbance, which is directly proportional to the number of living cells in the culture. Data were collected for three replicates.

\section{Results and discussion}

\subsection{FTIR and XRD analyses}

Figure 1A shows the FTIR spectra of copper oxide samples obtained by using nitrate (figure $1 \mathrm{~A}$; a), acetate (figure 1A; b), chloride (figure 1A; c) and sulphate (figure 1A; d) precursors. The spectra were analysed by correlating the observed peaks with the characteristic peaks for $\mathrm{CuO}$. Each spectrum shows three intense bands around 526, 605 and $675 \mathrm{~cm}^{-1}$ corresponding to metal oxide bond [29]. The strong absorption bands positioned at around 526 and $605 \mathrm{~cm}^{-1}$ can be 

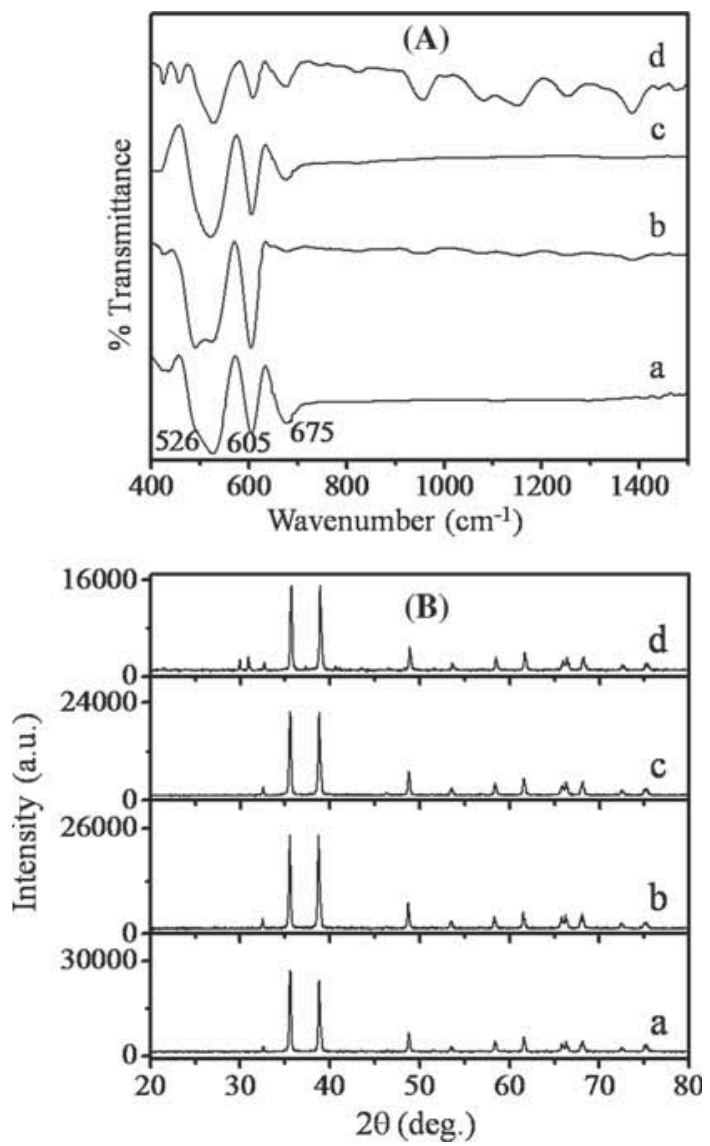

Figure 1. (A) Fourier transform infrared spectra and (B) X-ray diffraction patterns of copper oxide obtained using various precursors of copper (a) nitrate, (b) acetate, (c) chloride and (d) sulphate.

correlated to the $\mathrm{Cu}-\mathrm{O}$ asymmetric stretching and wagging vibrations, respectively, confirming the formation of pure phase $\mathrm{CuO}$ [30-33].

The XRD patterns of copper oxide samples obtained using various precursors; nitrate (sample a), acetate (sample b), chloride (sample c) and sulphate (sample d) are shown in figure $1 \mathrm{~B}$. The sharp peaks located at $2 \theta, 35.50$ and $38.73^{\circ}$ in the XRD represent the $(-111)$ and (111) planes that can be indexed to the pure monoclinic phase of copper oxide $(\mathrm{CuO}$; JCPDS card no. 80-1917) nanoparticles with a high degree of crystallinity as indicated by the peak intensities and peak widths [26,34].

A comparison of the diffractograms of the copper oxide samples shows the following order of crystallinity with reference to the precursors nitrate $>$ acetate $>$ chloride $>$ sulphate. The three most intense peaks observed in the diffraction pattern of each sample were selected to calculate the average crystallite size by using the Scherrer equation (equation (3)) [27].

$$
d=\frac{k \lambda}{\beta \cos \theta},
$$

where $d$ is the crystallite size, $\lambda$ the wavelength of the $\mathrm{CuK} \alpha$ used, $\beta$ the full-width at half-maximum of the diffraction peak, $k$ the shape factor and $\theta$ the angle of diffraction. The crystallite size obtained for the samples using different precursors (a-d) are found to be 49, 47, 45 and $43 \mathrm{~nm}$, respectively. The lowest crystallite size is obtained for copper oxide synthesized using sulphate precursor (d) while, the nitrate precursor (a) yields $\mathrm{CuO}$ with largest crystallite size.

\subsection{UV-visible analysis}

Optical absorption properties of the copper oxide were determined by using UV-visible spectroscopy. The UV-visible spectra of copper oxide samples exhibit a broad absorption peak in the range of $400-600 \mathrm{~nm}$ as shown in figure $2 \mathrm{~A}$. The plot of absorbance $v s$. wavelength shows a shift in the spectra towards longer wavelength as a function of decreasing particle size (quantum size effect), these results are in agreement with those of XRD analysis discussed earlier [35,36]. The Kubelka-Munk method was employed to estimate the theoretical band gap energies of the copper oxide nanoparticles [37]. The optical band gap of copper oxide nanoparticles was calculated according to the Tauc expression (equation (4)) $[22,38]$.

$$
\alpha=\frac{B\left(h v-E_{\mathrm{g}}\right)^{n}}{h v},
$$

where $h v$ is the incident photon energy, $\alpha$ the absorption coefficient, $B$ the material-dependent constant and $E_{\mathrm{g}}$ the optical band gap. The value of $n$ depends on the nature of transition, it takes the values as $1 / 2,3 / 2,2.0$ or 3.0 depending on whether the transition is direct allowed, direct forbidden, indirect allowed and indirect forbidden, respectively.

Optical band gap was determined from the plot of $(\alpha h v)^{1 / 2}$ $v s$. photon energy ( $h v$ ) (figure 2B). The value of $E_{\mathrm{g}}$ is found to vary between 1.35 and $1.38 \mathrm{eV}$, the values are observed to be close to the reported value for $\mathrm{CuO}$ nanoparticles $(1.4 \mathrm{eV})$ $[2,22]$. As the crystallite size of the copper oxide samples decreases, the band gap energy is seen to increase due to quantum confinement effect $[31,32,34,35]$. These results indicate that $\mathrm{CuO}$ nanoparticles could be used in optoelectronics and photovoltaic applications [23]. Further, figure 2C exhibits the plot of absorption coefficient $(\alpha)$ as a function of wavelength for the copper oxide nanoparticles. The absorption coefficient tends to decrease exponentially as a function of wavelength. This behaviour is typical for semiconductors and can arise due to various reasons such as internal electric fields within the crystal, deformation of lattice due to strain caused by imperfections and inelastic scattering of charge carriers by phonons $[22,23]$.

\subsection{SEM analysis}

Figure 3 shows the scanning electron micrographs of copper oxide samples obtained using (a) nitrate, (b) acetate, (c) 

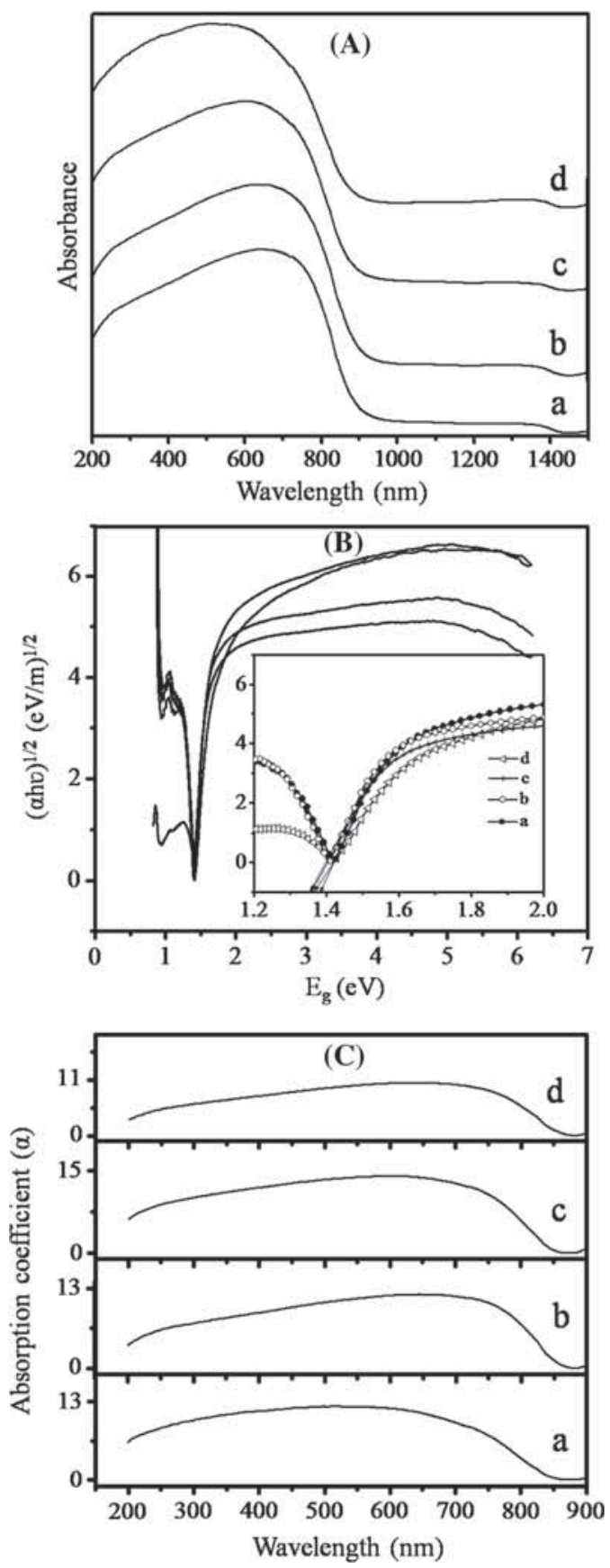

Figure 2. (A) UV-visible absorption spectra, (B) Kubelka-Munk plot and $(\mathbf{C})$ variations of absorption coefficient as a function of wavelength of copper oxide samples a-d.

chloride and (d) sulphate precursors. The samples show the presence of rectangular-shaped particles and rods. In case of copper oxide synthesized with nitrate and chloride precursors, the edges are distinct (figure $3 \mathrm{a}$ and $\mathrm{c}$ ) while, the samples obtained with sulphate (figure 3d) and acetate (figure 3b) precursors exhibit diffused structure. All the samples show the formation of nanorods with diameter and length varying between $0.3-1.5$ and $0.9-2.5 \mu \mathrm{m}$, respectively (figure 3 ).

\subsection{Zeta potential analysis}

The zeta potential values of the $\mathrm{CuO}$ nanoparticles synthesized with nitrate, acetate and sulphate precursors of copper were observed to be $-23.78 \pm 0.95,-11.86 \pm$ 1.06 and $-22.33 \pm 0.85 \mathrm{mV}$, respectively. The negative zeta potential value observed for $\mathrm{CuO}$ nanoparticles synthesized with nitrate, acetate and sulphate precursors confirms good colloidal stability of the synthesized nanoparticles preventing agglomeration [39-45]. However, $\mathrm{CuO}$ obtained with chloride precursor had positive zeta potential $(9.40 \pm 1.86 \mathrm{mV})$ implying relatively lower stability of the particles in the colloidal solution as compared to other samples [46].

\subsection{Antibacterial activities}

The antibacterial activity of copper oxide nanoparticles was investigated by studying the growth profile and by colony count method using human pathogenic bacteria such as E. coli and S. aureus.

Figure 4 shows the growth profiles of (A) E. coli and (B) $S$. aureus in terms of absorbance at different time intervals and concentrations of the nanoparticles, $0.05-0.3 \mathrm{mg} \mathrm{ml}^{-1}$ for $E$. coli and $0.01-0.7 \mathrm{mg} \mathrm{ml}^{-1}$ for $S$. aureus. As noted from figure 4 , a significant inhibition in the growth of bacteria is observed in presence of copper oxide nanoparticles when compared with control. To study the growth profiles, the concentrations of $\mathrm{CuO}$ nanoparticles were varied between $0.05-0.3$ and $0.01-0.7 \mathrm{mg} \mathrm{ml}^{-1}$ for $E$. coli (figure 4A) and $S$. aureus (figure 4B), respectively.

The absorbance of the control is highest while, in presence of $\mathrm{CuO}$ nanoparticles, there is a significant decrease in absorbance as a function of concentration of nanoparticles. Hence, the antibacterial effect of copper oxide nanoparticles increases with concentration. The concentration of nanoparticles at which maximum decrease in the slope value of the growth profile is observed is called as the MIC, once achieved, the observed growth of bacteria is to be terminated. All the samples exhibit a minimum lag phase of around $2 \mathrm{~h}$

3.5a MIC: The MIC of copper oxide samples for $E$. coli and $S$. aureus ranges between $0.15-0.3$ and $0.1-0.65 \mathrm{mg} \mathrm{ml}^{-1}$, respectively. In case of E. coli, the MIC follows the order as (a: $\left.0.3 \mathrm{mg} \mathrm{ml}^{-1}\right)>\left(\right.$ b: $\left.0.2 \mathrm{mg} \mathrm{ml}^{-1}\right)>\left(\right.$ c: $\left.0.15 \mathrm{mg} \mathrm{ml}^{-1}\right)=$ (d: $0.15 \mathrm{mg} \mathrm{ml}^{-1}$ ), while the sample shows the sequence as: (sample a: $0.65 \mathrm{mg} \mathrm{ml}^{-1}>$ sample b: $0.3 \mathrm{mg} \mathrm{ml}^{-1}>$ sample c: $0.2 \mathrm{mg} \mathrm{ml}^{-1}>$ sample d; $0.1 \mathrm{mg} \mathrm{ml}^{-1}$ for $S$. aureus (table 1).

The higher MIC values for $S$. aureus compared to $E$. coli can be attributed to the thicker peptidoglycan layer of bacterial cells, which makes it hard for $\mathrm{CuO}$ particles to penetrate the 

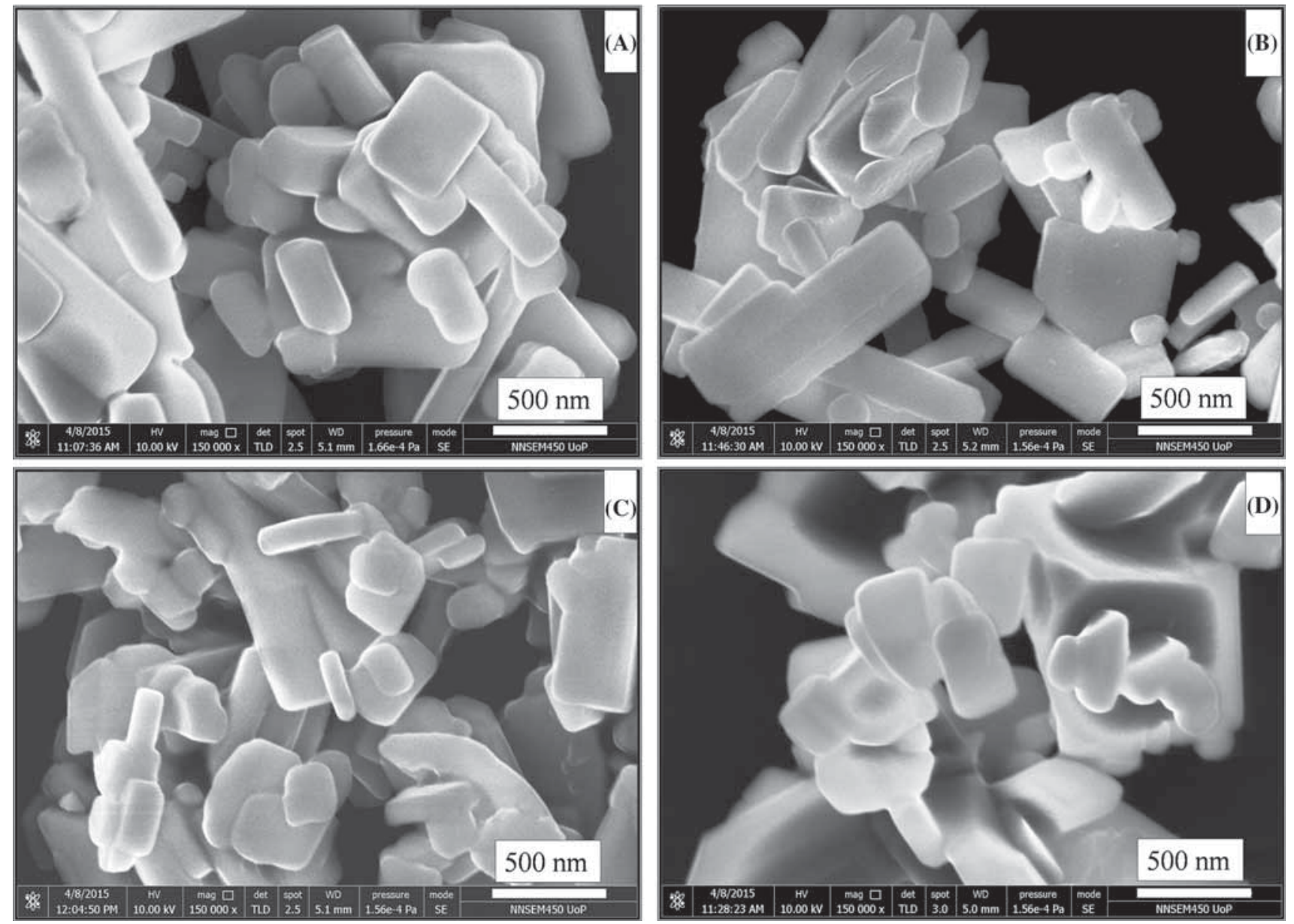

Figure 3. Scanning electron micrographs of copper oxide obtained using various precursors of copper (a) nitrate, (b) acetate, (c) chloride and (d) sulphate.

cell layer $[47,48]$. Contrary to this, the cell walls of $E$. coli are relatively thin, mainly consisting of peptidoglycan and outer layers of lipopolysaccharide, lipoprotein and phospholipid.

Further, differences are also observed in the MIC values for $\mathrm{CuO}$ samples obtained using different precursors. Sample d (sulphate precursor) exhibits lowest MIC concentration and highest antibacterial activity for both E. coli as well as $S$. aureus compared to other samples. This could be due to smaller size of the particles as a result of which the nanoparticles are able to interact with larger number of bacterial cells at a given concentration [29]. Also, during the synthesis of nanoparticles as the polarities and properties of different anions such as nitrate $\left(\mathrm{NO}_{3}^{-}\right)$, acetate $\left(\mathrm{CH}_{3} \mathrm{COO}^{-}\right)$, chloride $\left(\mathrm{Cl}^{-}\right)$and sulphate $\left(\mathrm{SO}_{4}^{2-}\right)$ vary, they lead to different types of interactions in the reaction bath, hence, the properties of the copper oxide nanoparticles are seen to be different so also, the antibacterial efficacy [5].

It is worth mentioning here that all the MIC values obtained in the present work are observed to be lower compared to those reported in the literature $[2,28,49]$. Hence, the $\mathrm{CuO}$ nanoparticles synthesized in the present work seem to possess high antibacterial potency. 3.5b Viable cell count and percentage of inhibition: The viable cell count was calculated by diluting the sample solution so as to obtain a measurable cell count and then the solution was spread on the LB agar plates (colony count method). The viable cell count of the treated cells grown on the plates was observed to decrease with increase in the concentration of nanoparticles as compared to control. For viable cell counts, the optical images of the Petri plates with the growth of bacterial colonies of E. coli and S. aureus after an exposure time of 4 and $6 \mathrm{~h}$, repectively, in presence of copper oxide samples are shown in figure $5 \mathrm{~A}$ and $\mathrm{B}$.

The number of colonies of both the cells were counted after the treatment with nanoparticles. From figure $5 \mathrm{~A}$ and $\mathrm{B}$, it is observed that the number of colonies decreases significantly after the treatment with nanoparticles. By fixing the MIC values of $\mathrm{CuO}$ samples, the percentage of inhibition was calculated by counting the viable cells (living cells) with reference to control by colony count method as shown in figure 5C and D. The control sample exhibits the highest number of bacterial colonies of E. coli and S. aureus, whereas samples treated with $\mathrm{CuO}$ show almost 95 to $98 \pm 2 \%$ growth inhibition (figure 5C and D) of bacteria. 

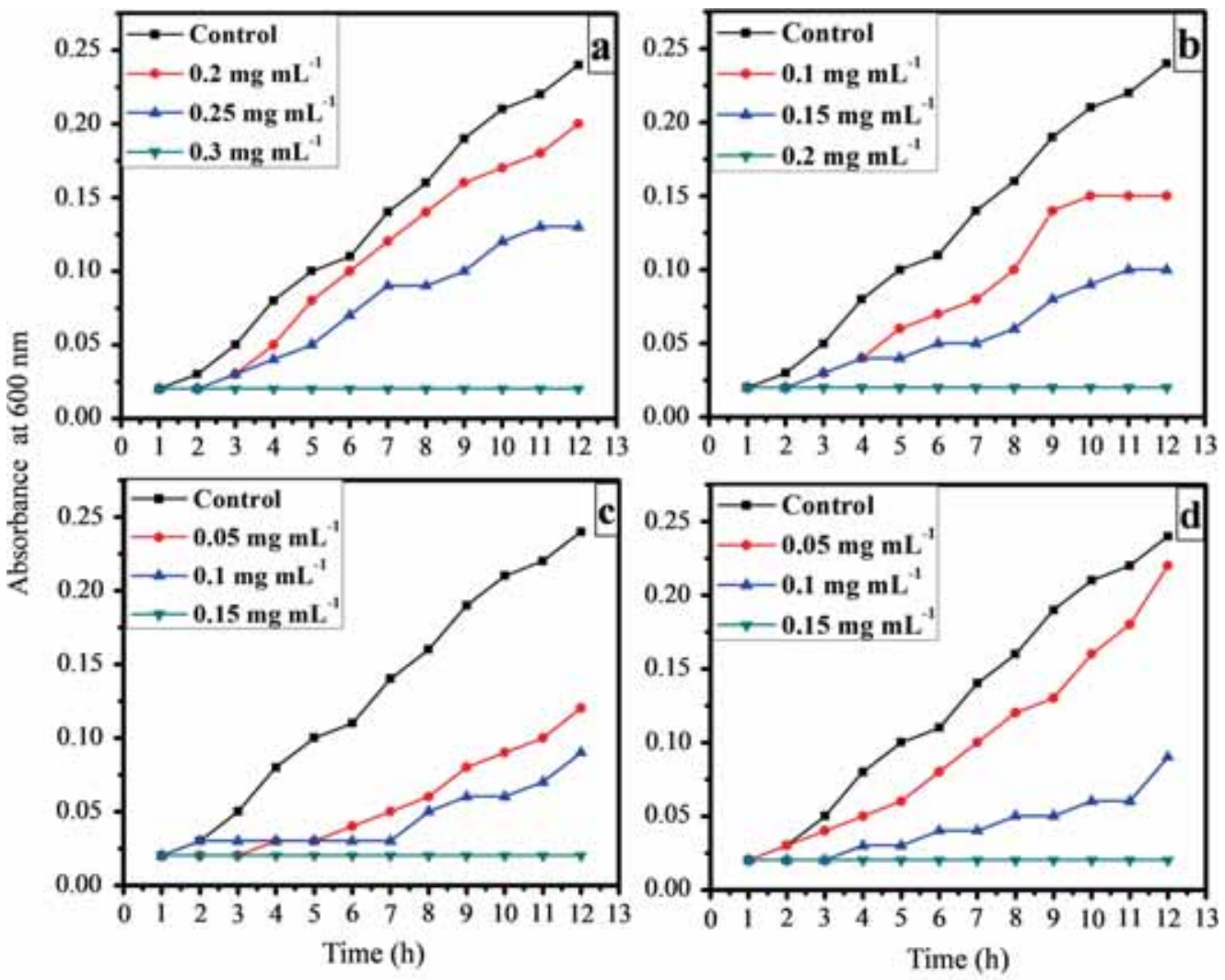

(B)
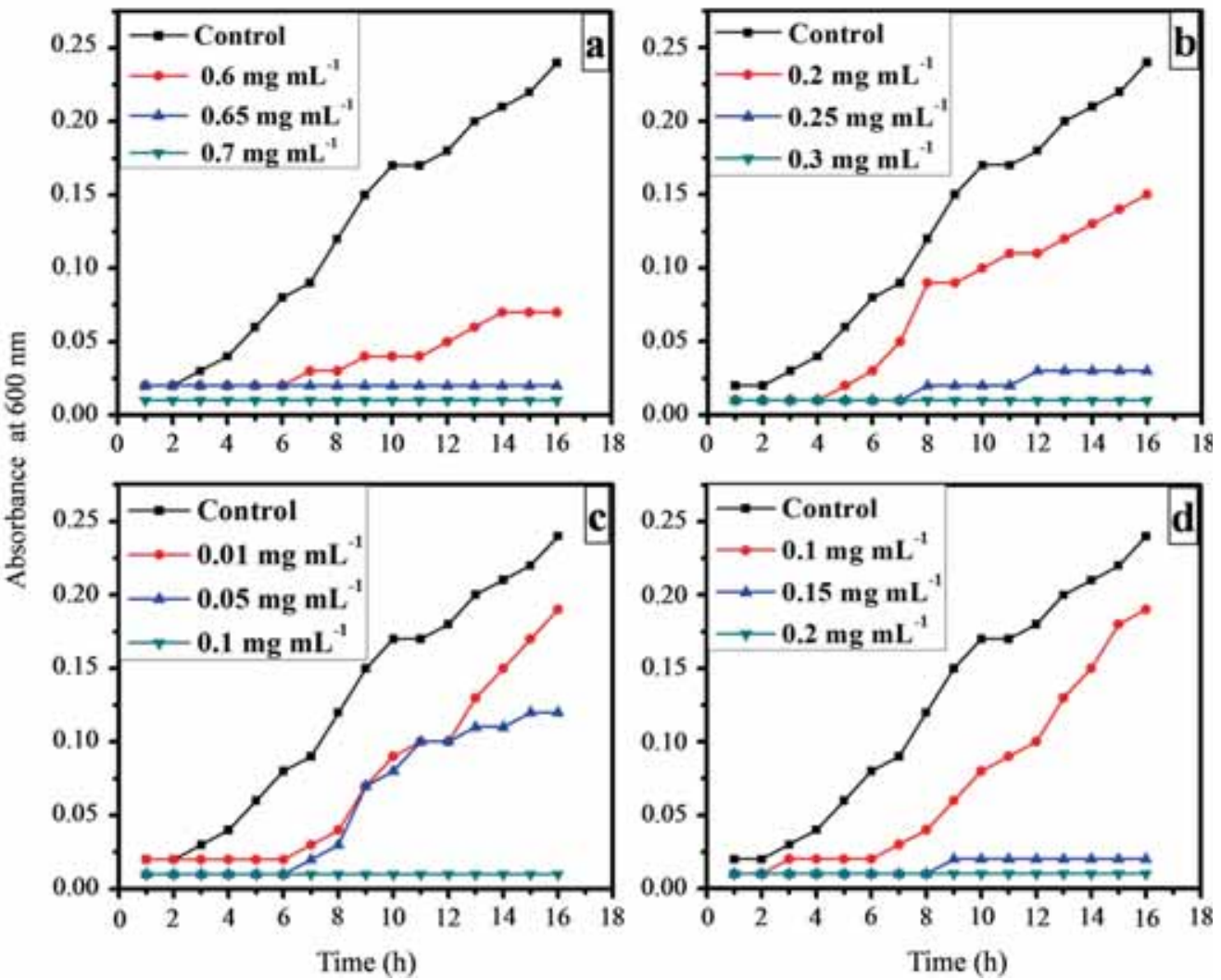

Figure 4. Growth profiles of (A) E. coli and (B) S. aureus as control and in presence of different concentrations of copper oxide samples a-d. 
3.5c Study of morphological changes in bacteria in presence of $\mathrm{CuO}$ nanoparticles: The morphological changes in the bacterial cell wall after treatment with copper oxide nanoparticles were observed by SEM. Figures 6 and 7A represent the SEM of control bacteria of E. coli and S. aureus strains, repectively, while figures 6 and 7B-I show the micrographs of bacteria treated with copper oxide samples. The micrographs of control samples show an integrated and undamaged structure of cell wall. The $E$. coli (figure 6A) bacterium cell shows a smooth rod-shaped structure with intact surface,

Table 1. MICs of copper oxide synthesized with different precursors of copper for E. coli and S. aureus bacterial strains.

\begin{tabular}{lcc}
\hline & \multicolumn{2}{c}{ MICs $\left(\mathrm{mg} \mathrm{ml}^{-1}\right)$} \\
\cline { 2 - 3 } Samples & E. coli & S. aureus \\
\hline a & 0.3 & 0.65 \\
$\mathrm{~b}$ & 0.2 & 0.3 \\
$\mathrm{c}$ & 0.15 & 0.2 \\
$\mathrm{~d}$ & 0.15 & 0.1 \\
\hline
\end{tabular}

while S. aureus (figure 7A) appears as grape-like clusters with large spherical structure. On the other hand, bacterial cells treated with copper oxide nanoparticles show damaged cell wall with complete disintegration of the cell (figures 6 and 7C, E, G, I). The results demonstrate that all the samples show about $99.0 \%$ bactericidal property towards both the bacterial strains.

The interaction between the nanoparticles and bacteria may arise due to electrostatic force of attraction between oppositely charged surfaces of nanoparticles and the bacterial cells or through generation of reactive oxygen species by the $\mathrm{CuO}$ nanoparticles, which attack the bacterial cell wall, resulting in oxidative stress on cell wall followed by cell damage $[1,2,4,40,48,50]$. In the present case, both the nanoparticles as well as the bacteria bear identical surface charges, and the generation of reactive oxygen species appears to be the factor causing cell damage and death. The nanoparticles are seen to accumulate on the bacterial cell membrane (figures 6 and $7 \mathrm{~B}, \mathrm{D}, \mathrm{F}, \mathrm{H}$ ) followed by adhesion and subsequently alteration/perforation of the cell membrane and finally, penetration of the nanoparticles inside the cell leading to cell death (figures 6 and 7C, E, G, I) [37,50,51].
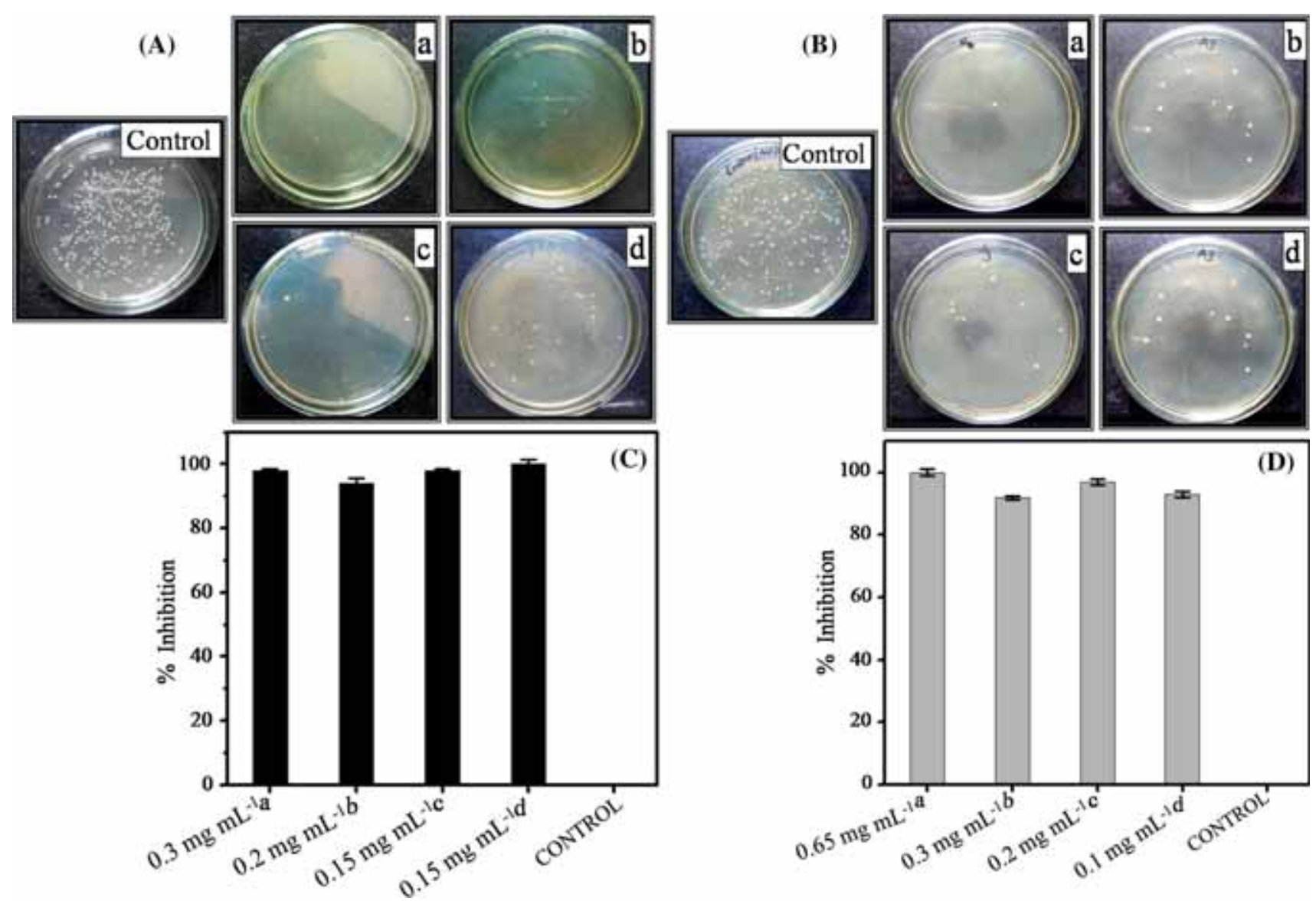

Figure 5. Viable cell count: (A) E. coli and (B) S. aureus and \% inhibition count: (C) E. coli and (D) S. aureus for control and copper oxide samples a-d by colony count method. 

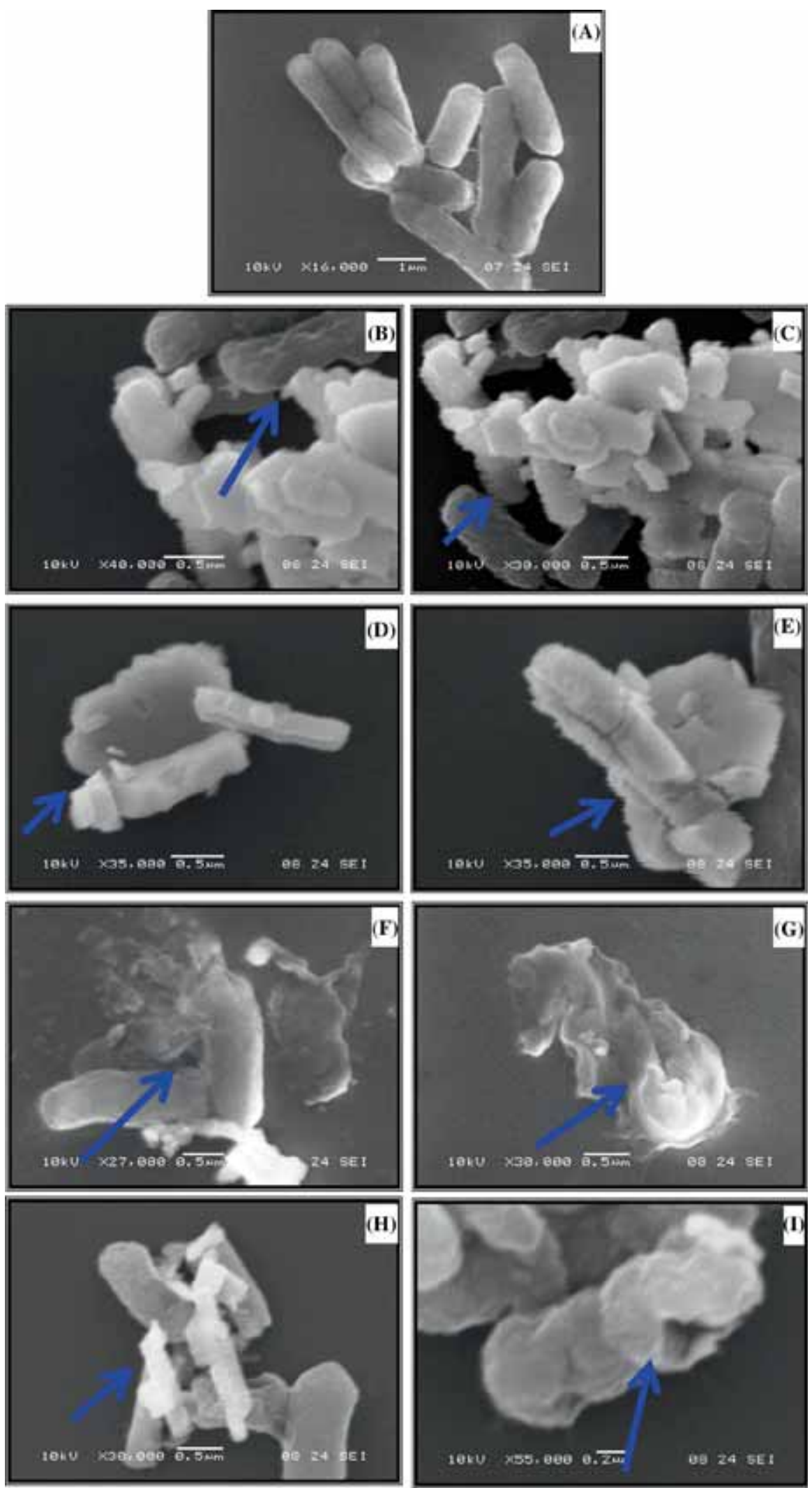

Figure 6. Scanning electron micrographs for E. coli: (A) in presence of control and different concentrations of copper oxide samples: a: $(\mathbf{B}$ and $\mathbf{C})$, b: $(\mathbf{D}$ and $\mathbf{E})$, c: $(\mathbf{F}$ and $\mathbf{G})$ and d: $(\mathbf{H}$ and I). 

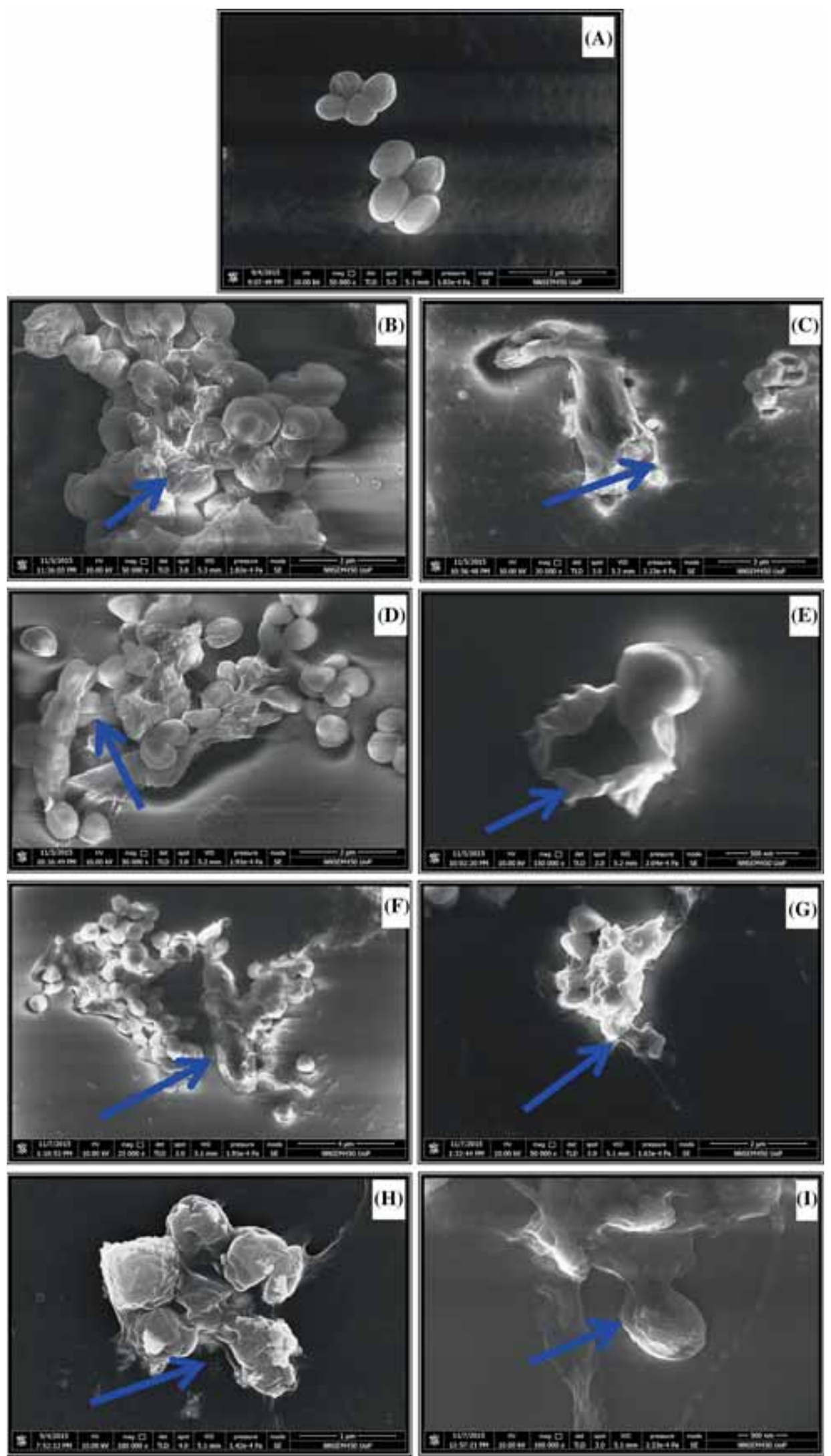

Figure 7. Scanning electron micrographs for S. aureus: (A) in presence of control and different concentrations of copper oxide samples: a: (B and $\mathbf{C}), \mathrm{b}$ : (D and $\mathbf{E}), \mathrm{c}$ : (F and $\mathbf{G})$ and d: (H and $\mathbf{I})$. 


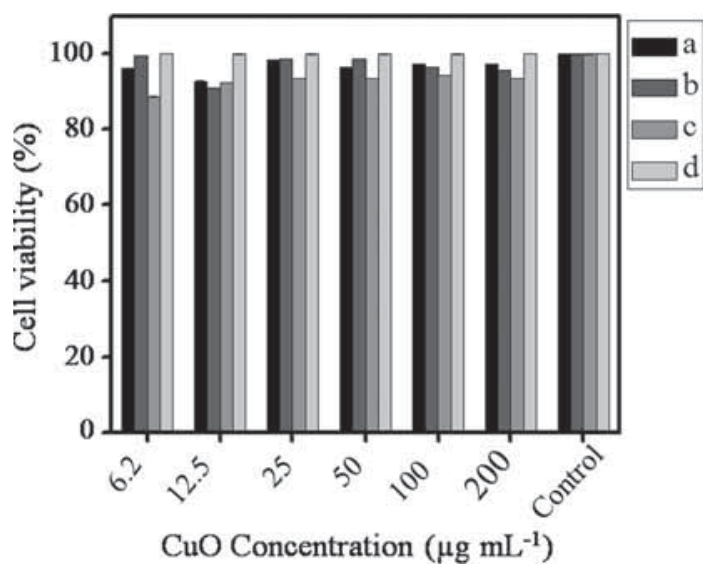

Figure 8. Cell viability of different concentrations of copper oxide samples a-d and control.

3.5d Cytotoxic activity: The cytotoxicity of copper oxide nanorods was tested on HeLa cell lines in the presence of untreated wells as control. An MTT assay was used to assess the effect of copper oxide on the cytotoxicity of HeLa cell lines [52]. Figure 8 summarizes the cell viability of HeLa cell lines incubated with different concentrations $\left(6.2-200 \mu \mathrm{g} \mathrm{ml}^{-1}\right)$ of copper oxide (samples a-d) for $24 \mathrm{~h}$.

As depicted in figure 8 , significant cell viability is observed in the presence of $\mathrm{CuO}$ nanoparticles as compared to untreated cell lines (control). The cell viability is found to be $90 \%$ even in the presence of higher concentration of $\mathrm{CuO}$ nanoparticles. These results indicate that copper oxide nanoparticles are non-toxic to the HeLa cell lines. Thus, one can conclude that the synthesized $\mathrm{CuO}$ nanoparticles appear to be promising candidates to be used as an effective antibacterial agent.

\section{Conclusions}

Copper oxide $(\mathrm{CuO})$ nanoparticles bearing monoclinic structure and good colloidal stability were prepared using templatefree hydrothermal method and were evaluated for their antibacterial activity. The results show that the copper precursors used for synthesizing $\mathrm{CuO}$ influence the structural and bactericidal properties of $\mathrm{CuO}$ nanoparticles. $\mathrm{CuO}$ obtained using sulphate precursor shows the lowest MIC values and highest antibacterial property. The antibacterial activity is found to be concentration as well as precursor-dependent and they do not show cytotoxicity.

\section{Acknowledgements}

The author (DVD) gratefully acknowledges Central Instrumentation Facility, Department of Chemistry, Savitribai Phule Pune University for SEM analysis, Indian Institute of Technology, Kanpur, for zeta potential analysis and National
Chemical Laboratory (NCL), Pune, for providing E. coli and $S$. aureus bacterial strains. Dr Kalpana Joshi (HOD) and Geetanjali Javir from Department of Biotechnology, Sinhgad College of Engineering, Pune, are acknowledged for helping in cytotoxicity studies. This research did not receive any specific grant from funding agencies in the public, commercial, or not-for-profit sectors.

\section{References}

[1] Thampi V A, Rajan S T, Anupriya K and Subramanian B 2015 J. Nanopart. Res. 1757

[2] Khashan K S, Sulaiman G M and Abdulameer F A 2016 Arab. J. Sci. Eng. 41301

[3] Chatterjee A K, Chakraborty R and Basu T 2014 Nanotechnology 25135101

[4] Grigore M E, Biscu E R, Holban A M, Gestal M C and Grumezescu A M 2016 Pharmaceuticals 975

[5] Hu C, Li Pei, Zhang W, Che Yanhao, Sun Y, Chi F et al 2017 Mater. Res. 20407

[6] Sayed F N and Polshettiwar V 2015 Sci. Rep. 59733

[7] Zhu H, Han D, Meng Z, Wu D and Zhang C 2011 Nanoscale Res. Lett. 6181

[8] Phiwdang K, Suphankij S, Mekprasart W and Pecharapa W 2013 Energy Procedia 34740

[9] Azimirad R, Safa S and Akhavan O 2015 Acta Phys. Pol. A 127 1727

[10] Gusattia M, Barroso G S, Maduro de Campos C E, Ribeiro de Souza D A, Almeida do Rosario J, Lima R B et al 2011 Mater. Res. 14264

[11] Kumar P S and Nesaraj A S 2015 J. Appl. Sci. Res. 11297

[12] Sinko K, Szabo G and Zrinyi M 2011 J. Nanosci. Nanotechnol. 111

[13] Rao N S and Rao M V 2015 Am. J. Mater. Sci. 566

[14] Hufschmid R, Arami H, Ferguson M, Gonzales M, Teeman E, Brush L N et al 2015 Nanoscale 711142

[15] Hasany S F, Ahmed I, Rajan J and Rehman A 2012 Nanosci. Nanotechnol. 2148

[16] Nassar M Y and Ahmed I S 2012 Mater. Res. Bull. 472638

[17] Qi J Q, Tian H Y, Li L T and Chan H L 2007 Nanoscale Res. Lett. 2107

[18] Yang Z, Xu J, Zhang W, Liu A and Tang S 2007 J. Solid State Chem. 1801390

[19] Srivastava R, Prathap M U and Kore R 2011 Colloids Surf. A 392271

[20] Dodoo-Arhin D, Leoni M and Scardi P 2012 Mol. Cryst. Liq. Cryst. 55517

[21] Sutradhar P, Saha M and Maiti D 2014 J. Nanostruct. Chem. 4 86

[22] Mallick P and Sahu S 2012 Nanosci. Nanotechnol. 271

[23] Son D I, You C H and Kim T W 2009 Appl. Surf. Sci. 2558794

[24] Wang H, Shen Q, Li X and Liu F 2009 Langmuir 253152

[25] Jadhav S, Gaikwad S, Nimse M and Rajbhoj A 2011 J. Clust. Sci. 22121

[26] Zhao J G, Liu S J, Yang S H and Yang S G 2011 Appl. Surf. Sci. 2579678

[27] Outokesh M, Hosseinpour M, Ahmadi S J, Mousavand T, Sadjadi S and Soltanian W 2011 Ind. Eng. Chem. Res. 503540 
[28] Das D, Nath B C, Phukon P and Dolui S K 2013 Colloids Surf. B 201430

[29] Azam A, Ahmed A S, Oves M, Khan M S and Memic A 2012 Int. J. Nanomed. 73527

[30] Papadimitropoulos G, Vourdas N, Vamvakas V E and Davazoglou D 2005 J. Phys. Conf. Ser. 10182

[31] Kannaki K, Ramesh P S and Geetha D 2012 Int. J. Sci. Eng. Res. 31

[32] El-Trass A, Elshamy H, El-Mehasseb I and El-Kemary M 2012 Appl. Surf. Sci. 2582997

[33] Vellora V, Padil T and Cernik M 2013 Int. J. Nanomed. 8889

[34] Zou Y, Li Y, Zhang N and Liu X 2011 Bull. Mater. Sci. 34967

[35] Rahimnejad S, Setayesh S R and Gholami M R 2008 J. Iran. Chem. Soc. 5367

[36] Bouazizi N, Bargougui R, Oueslati A and Benslama R 2015 Adv. Mater. Lett. 6158

[37] Bokare A, Sanap A, Pai M, Sabharwal S and Athawale A 2013 Colloids Surf. B 102273

[38] Hassan M S, Amna T, Yang O B, El-Newehy M H, Al-Deyab S S and Khil M S 2012 Colloids Surf. B 97201

[39] Cho W S, Duffin R, Thielbeer F, Bradley M, Megson I L, MacNee W et al 2012 Toxicol. Sci. 126469

[40] Siddiqui M A, Alhadlaq H A, Ahmad J, Al-Khedhairy A A, Musarra J and Ahamed M 2013 PLoS ONE 869534
[41] Yedurkar S M, Maurya C B and Mahanwar P A 2017 J. Mater. Environ. Sci. 81173

[42] Sankar R, Manikandan P, Malarvizhi V, Fathima T, Shivashangari K S and Ravikumar V 2014 Spectrochim. Acta, Part A: Mol. Biomol. Spectrosc. 121746

[43] Behera M and Giri G 2014 Mater. Sci.-Poland 32702

[44] Khanehzaei H, Ahmad M B, Shameli K and Ajdari Z 2015 Int. J. Electrochem. Sci. 10404

[45] Manikandan A and Sathiyabama M 2015 J. Nanomed. Nanotechnol. 6251

[46] Anandan D and Rajan K S 2012 Asian J. Sci. Res. 5218

[47] Wang M, Zhang W, Zheng X and Zhu P 2017 RSC Adv. 712144

[48] Chakraborty R, Sarkar R K, Chatterjee A K, Manju U, Chattopadhyay A P and Basu T 2015 Biochim. Biophys. Acta 1850 845

[49] Ren G, Hu D, Cheng E W, Vargas-Reus M A, Reip P and Allaker R 2009 Int. J. Antimicrob. Agents 33587

[50] Fu P P, Xia Q, Hwang H M, Ray P C and Yu H 2014 J. Food Drug Anal. 2264

[51] Naika H R, Lingaraju K, Manjunath K, Kumar D, Nagaraju G, Suresh D et al 2015 J. Taibah Univ. Sci. 97

[52] Giannousi K, Hatzivassiliou E, Mourdikoudis S, Vourlias G, Pantazaki A and Dendrinou-Samara C 2016 J. Inorg. Biochem. 16482 